\title{
Physicochemical properties and sensory acceptability of beetroot chips pre-treated by osmotic dehydration and ultrasound
}

\author{
Propriedades físico-químicas e aceitabilidade sensorial de chips \\ de beterraba pré-tratados por desidratação osmótica e ultrassom
}

\section{Ana Paula Peters ${ }^{1}$, Lindamir Tomczak Tullio1, Rafael Francisco de Lima1, Carlos Brian Oliveira de Carvalho², Zilmar Meireles Pimenta Barros ${ }^{2}$, Eunice Fraga Neta², Cátia Nara Tobaldini Frizon ${ }^{3}$, Suelen Ávila ${ }^{3 *}$ (D), Patrícia Moreira Azoubel ${ }^{4}$, Mônica de Caldas Rosa dos Anjos ${ }^{5}$, Sila Mary Rodrigues Ferreira ${ }^{5}$ (i)}

${ }^{1}$ Universidade Federal do Paraná, Curitiba/PR - Brasil

${ }^{2}$ Universidade Federal de Pernambuco, Recife/PE - Brasil

${ }^{3}$ Universidade Federal do Paraná, Programa de Pós-graduação em Alimentação e Nutrição, Setor de Ciências da

Saúde, Campus III, Curitiba/PR - Brasil

${ }^{4}$ Universidade Federal de Pernambuco, Programa de Graduação em Nutrição, Departamento de Engenharia Química, Recife/PE - Brasil

${ }^{5}$ Universidade Federal do Paraná, Programa de Pós-graduação em Alimentação e Nutrição, Departamento de Nutrição, Setor de Ciências da Saúde, Campus III, Curitiba/PR - Brasil

*Corresponding Author: Suelen Avila, Universidade Federal do Paraná, Programa de Pós-graduação em Alimentação e Nutrição, Campus III, Av. Prefeito Lothário Meissner, 632, Jardim Botânico, CEP: 80210-170, Curitiba/PR - Brasil e-mail suelenavila@ufpr.br

Cite as: Peters, A. P., Tullio, L. T., Lima, R. F., Carvalho, C. B. O., Barros, Z. M. P., Fraga Neta, E., Frizon, C. N. T., Ávila, S., Azoubel, P. M., Anjos, M. C. R., \& Ferreira, S. M. R. (2021). Physicochemical properties and sensory acceptability of beetroot chips pre-treated by osmotic dehydration and ultrasound. Brazilian Journal of Food Technology, 24, e2020068. https://doi.org/10.1590/1981-6723.06820

\begin{abstract}
Red beet (or beetroot) is highly nutritious and can be preserved by drying, in order to avoid wastage, to take advantage of crop surpluses, and to add value during the off-season. The objective of this study was to evaluate the effects of osmotic dehydration (OD) and ultrasound (US) pre-treatments on the nutritional quality and sensory characteristics of dried beetroot chips. The kinetics of moisture loss during OD and US were predicted by fitting the experimental data with thin-layer models. The physicochemical parameters (moisture, protein, lipid, carbohydrate, energy, ash, sodium and nitrate) and sensory properties (affective preference-ordering and acceptance test) were determined. Correlations between the treatments and the sensory acceptability evaluated by consumer's perceptions were performed by applying unsupervised chemometric techniques (Principal Component Analysis (PCA) and Hierarchical Cluster Analysis (HCA)). The two-term exponential model provided the best fit for the experimental drying data. The US treatment promoted a higher drying rate and lower lipid, ash and energy values, while the OD process resulted in higher ash and sodium values. Multivariate analysis revealed that the US and OD treatments improved the sensory properties of the beetroot chips. The US was more efficient pre-treatment for producing beet chips due to its leads a significant reduction on drying time and intermediate level of sensory preference.
\end{abstract}

Keywords: beet; ultrasound; osmotic dehydration; nutritional properties; sensory evaluation, multivariate analysis. 


\section{Resumo}

A beterraba vermelha é altamente nutritiva e pode ser preservada pela secagem, a fim de evitar desperdícios, aproveitar os excedentes das culturas e agregar valor durante a entressafra. O objetivo deste estudo foi avaliar os efeitos dos pré-tratamentos de desidratação osmótica (DO) e ultrassom (US) na qualidade nutricional e nas características sensoriais de chips de beterraba desidratados. A cinética de perda de umidade durante DO e US foi prevista pelo ajuste dos dados experimentais com modelos de camada fina. Foram determinados parâmetros físico-químicos (umidade, proteína, lipídio, carboidrato, energia, cinzas, sódio e nitrato) e propriedades sensoriais (ordem de preferência afetiva e teste de aceitação). As correlações entre os tratamentos e a aceitabilidade sensorial avaliada pelas percepções do consumidor foram realizadas aplicando técnicas quimiométricas não supervisionadas (Análise de Componentes Principais e Análise de Agrupamento Hierárquico). O modelo exponencial de dois termos forneceu melhor ajuste para os dados experimentais de secagem. O tratamento US promoveu maior taxa de secagem e menores valores de lipídios, cinzas e energia, enquanto o processo DO resultou em maiores valores de cinzas e sódio. A análise multivariada revelou que os tratamentos US e DO melhoraram as propriedades sensoriais dos chips de beterraba. US foi o pré-tratamento mais eficiente para a produção de chips de beterraba, em razão da redução significativa no tempo de secagem e do nível intermediário de preferência sensorial.

Palavras-chave: beterraba; ultrassom; desidratação osmótica; propriedades nutricionais; avaliação sensorial, análise multivariada.

\section{Introduction}

Beetroot provides valuable essential nutrients and contains a high concentration of bioactive compounds, which are responsible for health promotion and disease prevention (Chhikara et al., 2019). In order to avoid wastage, to take advantage of crop surpluses, and to add value during the off-season, beets can be preserved by drying. This process, in addition to being an alternative method to reduce post-harvest damage, increases shelf life, reduces weight and volume, and facilitates storage and transport (Medeiros et al., 2016). Conventional drying methods used in food processing to extend shelf life may result in physical, chemical and sensory alterations to the final product (Aadil et al., 2013).

However, in order to minimize heat damage in the drying process, pre-treatment techniques, such as osmotic dehydration and ultrasound, may be employed (Ricce et al., 2016). Osmotic dehydration is a process of partial water removal performed by the immersion of vegetable products into hypertonic solutions, usually sucrose or sodium chloride (Ahmed et al., 2016; Brochier et al., 2019; Mirzayi et al., 2018). In the drying of vegetables preceded by ultrasound (US) treatment, the ultrasonic waves applied to the food may form microchannels, therefore, increasing the porosity and facilitating the removal of water (da Rosa et al., 2019; Ricce et al., 2016).

The US pre-treatment and Osmotic Dehydration (OD) have been enhanced the mass transfer in different fruits and vegetable like persimmon (Bozkir et al., 2019; Bozkir \& Ergün, 2020; Ribeiro et al., 2016), pomegranate (Allahdad et al., 2019), plum (Rahaman et al., 2019), cranberries (Nowacka et al., 2018), carambola (Barman \& Badwaik, 2017), potato (Goula et al., 2017), mango (Xin et al., 2013), broccoli (Zhao et al., 2017), kiwi (Nowacka et al., 2014, 2017), carrots and strawberries (Konopacka et al., 2017; Villamiel et al., 2015). The main results obtained indicate that samples pretreated by US and OD compared with the untreated samples decreased drying time, enhanced the diffusion coefficients of water loss and showed a gain of solids (Amami et al., 2017; Barman \& Badwaik, 2017; Bozkir et al., 2019; Bozkir \& Ergün, 2020; Mierzwa \& Kowalski, 2016; Villamiel et al., 2015).

Elias et al. (2008) verified that the combination of OD and convective drying maintained the nutritional quality of dried persimmon cylinders showing good consumer acceptance, and the texture was the predominant sensory parameter, whereas appearance was the least important characteristic. Similarly, guavas 
that included dehydration by immersion were sensorially more accepted (Queiroz et al., 2007). According to Rahaman et al., (2019) the osmo-dehydrated plum in glucose showed an increased softness and the nutritional compounds like phenolics and antioxidant.

Sakooei-Vayghan et al. (2020) showed that higher retention of total phenolic content and vitamin C were observed to pre-treatment of OD in dried apricot, while the sample treated by US osmotic dehydration presented higher B-carotene and antioxidant activity. Konopacka et al. (2017) produced snacks of carrot slices applying US and enzymatic treatment and they not only had a positive effect on carotenoid retention but also led to a higher sensory appreciation of the dried carrot slices colour.

Bozkir \& Ergün (2020) analyzed the effect of sonication and OD applications on the quality of persimmon and they did not evidence a significant change in the total phenolic and bulk density. Allahdad et al. (2019) showed that the dried pomegranate arils presented higher color quality after US along with OD, but it showed losses of total anthocyanin content and increasing hardness, as compared to the osmo-dehydrated samples. The US pre-treatment combined with osmotic penetration effectively improved the quality of heat-pump dried tilapia fillets ( $\mathrm{Li}$ et al., 2017).

These technologies, besides accelerating drying, are simple and economically viable (Ricce et al., 2016). Thus, the aim of the present study was to evaluate the effects of OD) and US pre-treatment on the quality and sensory acceptability of beetroot chips.

\section{Materials and methods}

\subsection{Raw material and preparation}

The red beets (beetroot) (Beta vulgaris L.), cv. Early Wonder) were acquired from a farmer at the State Supply Center of Pernambuco (Ceasa/PE), in the city of Recife, Brazil. The beets were washed and sanitized by immersion for three minutes in chlorinated water $\left(200 \mathrm{mg} \mathrm{L}^{-1}\right.$ of active chlorine). Subsequently, the inedible parts, except the peel, were manually removed and discarded. The beets were cut using a food processor into slices of $2 \mathrm{~mm}$ in thickness and $5 \mathrm{~cm}$ in diameter and then divided in half. For the US treatment, the beet slices were previously placed in a beaker containing distilled water at a ratio of sample: water of $1: 4(\mathrm{w} / \mathrm{w})$ and placed in an ultrasonic bath (Unique ${ }^{\circledR}$, Brazil) at $30{ }^{\circ} \mathrm{C}$ for 20 minutes, using a frequency of $25 \mathrm{kHz}$ and intensity equal to $4,870 \mathrm{~W} / \mathrm{m}^{2}$ (Azoubel et al., 2010; Souza da Silva et al., 2019). The osmotic treatment (OD) was carried out by immersing the samples for two minutes in 5\% sodium chloride solution $(\mathrm{NaCl})$, a ratio of 1:4 samples to the solution (weight basis). After the pre-treatments, the beet slices were removed from the solution, drained in a sieve for one minute, and dried with the aid of absorbent paper (Kiani et al., 2018).

\subsection{Drying process}

The design of the processing set was based in Souza da Silva et al. (2019). The samples without pre-treatment (C) and with pre-treatment (OD and US) were dried at $60^{\circ} \mathrm{C}$. The samples were weighed every 15 minutes until reaching the dynamic equilibrium between the sample and the air. The study of drying kinetics was performed using data from the dimensionless Moisture Ratio (MR) as a function of process time (Equation 1) using thin-layer models (Table 1) to adjust the experimental data obtained, as follows:

$\mathrm{MR}=\frac{\mathrm{Xt}-\mathrm{Xe}}{\mathrm{Xo}-\mathrm{Xe}}$

where $\mathrm{X}_{\mathrm{t}}$ is the sample moisture content in time $t$ (g water/g dry mass); $\mathrm{X}_{\mathrm{o}}$ is the initial moisture content ( $\mathrm{g}$ water/g dry mass); $\mathrm{X}_{\mathrm{e}}$ is the equilibrium moisture content ( $\mathrm{g}$ water $/ \mathrm{g}$ dry mass). 
Table 1. Mathematical layer models used for mathematical of dehydrated beet type chips.

\begin{tabular}{ccc}
\hline Model & Equation & Reference \\
\hline Single exponential & $\mathrm{MR}=\exp (-\mathrm{kt})$ & Abe \& Afzal (1997) \\
\hline Page & $\mathrm{MR}=\exp \left(-\mathrm{kt}^{\mathrm{v}}\right)$ & Page (1949) \\
\hline Henderson and Pabis & $\mathrm{MR}=\mathrm{a} \exp (-\mathrm{kt})$ & Henderson \& Pabis (1961) \\
\hline Logarithmic & $\mathrm{MR}=\mathrm{a} \exp (-\mathrm{kt})+\mathrm{c}$ & Yaldiz et al. (2001) \\
\hline Two-term exponential & $\mathrm{MR}=\mathrm{a} \exp \left(-\mathrm{k}_{\mathrm{o}} \mathrm{t}\right)+\mathrm{b} \exp \left(-\mathrm{k}_{\mathrm{l}} \mathrm{t}\right)$ & Ozdemir \& Devres (1999) \\
\hline
\end{tabular}

The parameters of the mathematical model were obtained by nonlinear regression using STATISTICA 7.0 software (StatSoft, USA). In order to verify the fit of the models to the experimental data, the relative average error (P) was calculated (Equation 2) and the determination coefficient $\mathrm{R}^{2}$; the model that was considered as predictive presented a $p$-value below $10 \%$ (Lomauro et al., 1985). $M R$ represents the moisture ratio, $k$ is the drying rate constant, $t$ is the drying time, $a, b, c, v$ are the empirical constants in drying models.

$P=\frac{100}{N} \sum \frac{\left|\mathrm{M}_{\mathrm{p}}-\mathrm{M}_{\mathrm{e}}\right|}{\mathrm{M}_{\mathrm{p}}}$

where $M_{p}$ is the value predicted by the model; $M_{e}$ is the value obtained experimentally and $N$ is the number of experimental points.

\subsection{Physicochemical parameters}

The moisture content was determined by heating the sample to a constant weight in an oven at $105 \pm 2{ }^{\circ} \mathrm{C}$ (Association of Official Analytical Chemists, 2008); ash was determined by gravimetric methodology after calcination of the sample in the furnace at $550{ }^{\circ} \mathrm{C} \pm 2{ }^{\circ} \mathrm{C}$ for at least $6 \mathrm{~h}$ (Association of Official Analytical Chemists, 2008); protein ( $\%$ total nitrogen $\times 6.25$ ) was determined by the Kjeldahl method (Association of Official Analytical Chemists, 2008); lipids were determined after sample extraction in chloroform, methanol and water (1:2:0.8) (Bligh \& Dyer, 1959); carbohydrate was obtained by difference (IAL, 2008); the energetic value was calculated by multiplying the carbohydrate and protein content by $4 \mathrm{kcal} / \mathrm{g}$ and lipids by $9 \mathrm{kcal} / \mathrm{g}$; sodium chloride by volumetry (Instituto Adolfo Lutz, 2008) and nitrate by titration (Association of Official Analytical Chemists, 2008).

\subsection{Sensory analysis}

The sensory analysis was performed in a training session using 124 volunteers, who were aged 18-22 and who were low-grade athletes from a soccer team. Before beginning the test, the untrained judges signed an informed consent form (in Portuguese Termo de Consentimento Livre e Esclarecido (TCLE)). The samples were served in sealed individual packages and coded with three digits, which were chosen at random. The judges were handed $2 \mathrm{~g}$ of beet chips from the three treatments: $\mathrm{C}$ (control- untreated), OD (osmotic dehydration) and US (ultrasound). After tasting each sample, the volunteers were instructed to drink water in order to eliminate residual elements. The affective preference-ordering test was performed by choosing the treatments that were least preferred (1), intermediate (2) and preferred (3) by the judges. The acceptance test was carried out using a nine-point, structured hedonic scale, ranging from $1=$ "extremely disliked" to 9= "extremely liked", according to Fakhouri et al. (2015). The project was approved by the Research Ethics Committee (CEP) of the Federal University of Paraná, Brazil under No. 1322.349. 


\subsection{Statistical analysis}

The study was conducted using a completely randomized design. The chemical analysis was performed in triplicate and presented in mean and standard deviation. The results were submitted to Analysis of Variance (ANOVA) and, in the case of significant difference, the averages were compared using Tukey's test $(p \leq 0.05)$. Principal Component Analysis (PCA) and Hierarchical Cluster Analysis (HCA) were performed using STATISTICA software (StatSoft version 7.0) to describe the relationship between the beet samples $(n=3)$ and sensory consumers $(n=124)$ in the hedonic scale of preference. In the case of PCA, eigenvalues greater than 1.0 were adopted to explain the projection of the samples on the graph, and the two-dimensional analysis was based on linear correlations. In the case of HCA, Euclidean metric and Ward's method were used to suggest groups of similar samples (Ávila et al., 2019).

\section{Results and discussion}

The resulting values for the drying model parameters are shown in Table 2. The data fitted well, with the two-term exponential model presenting an $\mathrm{R}^{2}$ value of 0.99 and the lowest values of error, indicating a good fit. The moisture content decreased exponentially during the drying time (Figure 1).

Table 2. Parameters, average relative error (E), and $\mathrm{R}^{2}$ determination coefficient results for dehydrated beet type chips.

\begin{tabular}{|c|c|c|c|c|}
\hline Samples & Models & Model parameters & E (\%) & $\mathbf{R}^{2}$ \\
\hline \multirow{12}{*}{ Control } & \multirow{4}{*}{ Two-term exponential } & $a=0.55$ & \multirow{4}{*}{0.98} & \multirow{4}{*}{0.99} \\
\hline & & $\mathrm{k}_{\mathrm{o}}=0.04$ & & \\
\hline & & $\mathrm{b}=0.45$ & & \\
\hline & & $\mathrm{k}_{1}=0.14$ & & \\
\hline & \multirow{2}{*}{ Page } & $\mathrm{k}=0.07$ & \multirow{2}{*}{85.71} & \multirow{2}{*}{0.74} \\
\hline & & $\mathrm{v}=18.67$ & & \\
\hline & \multirow{3}{*}{ Logarithmic } & $a=0.87$ & \multirow{3}{*}{74.03} & \multirow{3}{*}{0.88} \\
\hline & & $\mathrm{k}=1.89$ & & \\
\hline & & $\mathrm{c}=0.13$ & & \\
\hline & Single exponential & $\mathrm{k}=0.06$ & 9.53 & 0.99 \\
\hline & Henderson and Pabis & $a=0.99$ & 22.98 & 0.99 \\
\hline & & $\mathrm{k}=0.06$ & & \\
\hline \multirow{12}{*}{ DO } & \multirow{4}{*}{ Two-term exponential } & $a=0.67$ & \multirow{4}{*}{5.71} & \multirow{4}{*}{0.99} \\
\hline & & $\mathrm{k}_{\mathrm{o}}=0.03$ & & \\
\hline & & $\mathrm{b}=0.33$ & & \\
\hline & & $\mathrm{k}_{1}=0.14$ & & \\
\hline & \multirow{2}{*}{ Page } & $\mathrm{k}=0.07$ & \multirow{2}{*}{87.50} & \multirow{2}{*}{0.57} \\
\hline & & $\mathrm{v}=18.78$ & & \\
\hline & \multirow{3}{*}{ Logarithmic } & $\mathrm{a}=0.84$ & \multirow{3}{*}{170.48} & \multirow{3}{*}{0.81} \\
\hline & & $\mathrm{k}=1.63$ & & \\
\hline & & $\mathrm{c}=0.16$ & & \\
\hline & Single exponential & $\mathrm{k}=0.04$ & 26.00 & 0.99 \\
\hline & Henderson and Pabis & $a=0.98$ & 24.54 & 0.99 \\
\hline & & $\mathrm{k}=0.04$ & & \\
\hline \multirow{12}{*}{ US } & \multirow{4}{*}{ Two-term exponential } & $\mathrm{a}=0.54$ & \multirow{4}{*}{4.37} & \multirow{4}{*}{0.99} \\
\hline & & $\mathrm{k}_{\mathrm{o}}=1.83$ & & \\
\hline & & $\mathrm{b}=0.46$ & & \\
\hline & & $\mathrm{k}_{1}=0.05$ & & \\
\hline & \multirow{2}{*}{ Page } & $\mathrm{k}=0.07$ & \multirow{2}{*}{83.33} & \multirow{2}{*}{0.91} \\
\hline & & $\mathrm{v}=19.07$ & & \\
\hline & \multirow{3}{*}{ Logarithmic } & $\mathrm{a}=0.92$ & & \\
\hline & & $\mathrm{k}=2.19$ & 148.54 & 0.96 \\
\hline & & $\mathrm{c}=0.08$ & & \\
\hline & Single exponential & $\mathrm{k}=0.09$ & 49.83 & 0.99 \\
\hline & Henderson and Pabis & $a=0.99$ & 49.77 & 0.99 \\
\hline & & $\mathrm{k}=0.09$ & & \\
\hline
\end{tabular}




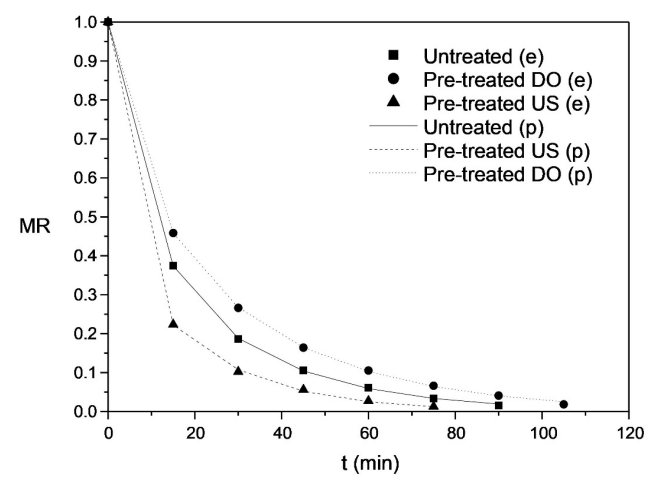

Figure 1. Experimental (point) (e) and predicted moisture content ratio (p) (MR) for dehydrated beet type chips curves using two-term exponential model (lines).

However, the US treatment promoted a shorter drying time than the untreated (C) sample and the sample pre-treated by OD, with times of $76 \mathrm{~min}, 85 \mathrm{~min}$, and $103 \mathrm{~min}$, respectively. Similar results were found by previous studies with different matrices (Allahdad et al., 2019; Amami et al., 2017; Barman \& Badwaik, 2017; Bozkir et al., 2019; Bozkir \& Ergün, 2020; Prithani \& Dash, 2020). In less than 20 minutes, the US presented a decrease in moisture of $80 \%$, indicating that ultrasonic pre-treatment can facilitate the removal of moisture, decreasing drying time, increasing product yield and reducing operating and maintenance costs (Medeiros et al., 2016; Ricce et al., 2016). The force generated by the ultrasonic mechanism is greater than the surface tension that keeps the water inside the plant capillaries, causing the creation of microscopic channels that reduce the boundary layer of diffusion and increasing the transfer of mass by convection.

The time to the beet chips reach $9.06 \mathrm{~g} / 100 \mathrm{~g}$ final moisture using the US was $26 \%$ lower than those dried only with conventional drying. Amami et al. (2017) also needed about the $10.88 \%$ to $28.25 \%$ less time to achieve $90 \%$ reduction in moisture content with Ultrasound-Assisted Osmotic Dehydration (UAOD) for strawberry halves. Besides, Bozkir \& Ergün (2020) have evidenced that the drying rates and effective diffusivities increased with the increase in US treatment times for persimmon fruits and the drying time with US (30 min) and OD decreased significantly by $46 \%$. Ribeiro et al. (2016) observed that the drying time reduction contributes to preserving the sensory and physicochemical characteristics of the samples.

During the osmotic dehydration process, the semipermeable membrane of the plant cell structure produces a potential chemical difference between water and nutrients in the osmotic environment; the incorporation of solids hinders the elimination of water during drying, resulting in a higher internal resistance and lower drying rate (Azoubel et al., 2015; Medeiros et al., 2016; Ricce et al., 2016). This is clearly shown in Figure 1, where the longest drying time was for OD pre-treatment. During the osmotic process, three simultaneous mass transfer flows occur: increase of solutes from the solution to the sample, migration of water from inside of the sample to the medium and migration of some constituents from the sample to the medium. In addition, the plant tissue is permeable to $\mathrm{Na}^{+}$and $\mathrm{Cl}^{-}$ions and the immersion process of the samples in sodium chloride solution increased the ash and sodium values of the beet chips, Table 3 (Borin et al., 2008). However, the amount of sodium in the portion of the beet chips for all the studied samples met the recommended limit for sodium consumption, which is less than $3 \mathrm{~g}$ per day.

Table 3. Centesimal composition of dehydrated beet type chips.

\begin{tabular}{cccc}
\hline Analysis & Untreated & DO & US \\
\hline Moisture $(\mathrm{g} / 100 \mathrm{~g})$ & $6.04 \pm 0.06^{\mathrm{b}}$ & $5.27 \pm 0.14^{\mathrm{c}}$ & $9.60 \pm 0.43^{\mathrm{a}}$ \\
\hline Protein $(\mathrm{g} / 100 \mathrm{~g})$ & $1.88 \pm 0.06^{\mathrm{ab}}$ & $1.77 \pm 0.05^{\mathrm{b}}$ & $1.95 \pm 0.06^{\mathrm{a}}$ \\
\hline Lipid $(\mathrm{g} / 100 \mathrm{~g})$ & $1.14 \pm 0.12^{\mathrm{a}}$ & $1.41 \pm 0.09^{\mathrm{a}}$ & $0.53 \pm 0.01^{\mathrm{b}}$ \\
\hline Carbohydrate $(\mathrm{g} / 100 \mathrm{~g})$ & $81.67 \pm 0.15^{\mathrm{a}}$ & $77.75 \pm 0.18^{\mathrm{c}}$ & $79.13 \pm 0.46^{\mathrm{b}}$ \\
\hline Energy & $344.46 \pm 0.48^{\mathrm{a}}$ & $330.77 \pm 0.53^{\mathrm{b}}$ & $329.09 \pm 1.88^{\mathrm{c}}$ \\
\hline Ash $(\mathrm{g} / 100 \mathrm{~g})$ & $9.27 \pm 0.02^{\mathrm{b}}$ & $13.80 \pm 0.04^{\mathrm{a}}$ & $8.79 \pm 0.21^{\mathrm{c}}$ \\
\hline Sodium $(\mathrm{g} / 100 \mathrm{~g})$ & $0.29 \pm 0.01^{\mathrm{b}}$ & $0.71 \pm 0.01^{\mathrm{a}}$ & $0.27 \pm 0.01^{\mathrm{b}}$ \\
\hline Nitrate $(\mathrm{mg} / 100 \mathrm{~g})$ & $739.43 \pm 5.69^{\mathrm{b}}$ & $731.85 \pm 3.28^{\mathrm{b}}$ & $858.88 \pm 0.01^{\mathrm{a}}$ \\
\hline
\end{tabular}

Mean and standard deviation followed by equal letters indicate that there was no statistical difference at the $p<0.05$ level. 
The values for the energy levels of the beet chips were higher $(37.67 \mathrm{kcal} / 100 \mathrm{~g})$ than for the same amount of in nature beet (World Health Organization, 2016). The energy, lipid and ash contents for the US pretreatment were lower than the OD and $\mathrm{C}$ treatments (Table 3). Nevertheless, there was no significant difference in relation to the protein and lipid contents among OD and $\mathrm{C}$, which shows that OD did not influence the loss of these nutrients. The US probably causes a disturbance in plant cells, facilitating the release of cellular matrix components (Ricce et al., 2016).

When statistically evaluating Table 3, it is observed that the drying process without pre-treatment influenced the ash, sodium and nitrate content. Regarding the nitrate content, the US treatment presented the highest amounts of nitrate, suggesting that this method promotes the retention of water, which might contain nitrate in its composition (Pingret et al., 2013). According to the acceptable daily intake for dietary nitrate, established by the Joint FAO/WHO Expert Committee on Food Additives, an adult of $70 \mathrm{~kg}$ can ingest on average $30 \mathrm{~g}$ of dehydrated beet chips. A six-year-old child of approximately $20 \mathrm{~kg}$ can ingest $9 \mathrm{~g}$, while a one-year-old child weighing approximately $10 \mathrm{~kg}$ can ingest $4.5 \mathrm{~g}$ of dehydrated beet chips, which corresponds to four slices. Consumption is prohibited for children aged under three months (Food and Agriculture Organization, 2003).

The preferred sample in the sensory sorting testing was OD, followed by the US sample, which received an intermediate rating; the least preferred sample was the untreated sample (C) (Figure 2). Furthermore, according to physicochemical results, the OD sample showed lower moisture and higher lipid, ash and sodium content. The present findings are corroborated by previous studies that also obtained better nutritional quality and sensory acceptability with osmotic pre-treatments for plum (Rahaman et al., 2019), mango (Sanjinez-Argandoña et al., 2018), carrot (Tadesse et al., 2016), persimmon (Elias et al., 2008) and guavas (Queiroz et al., 2007).

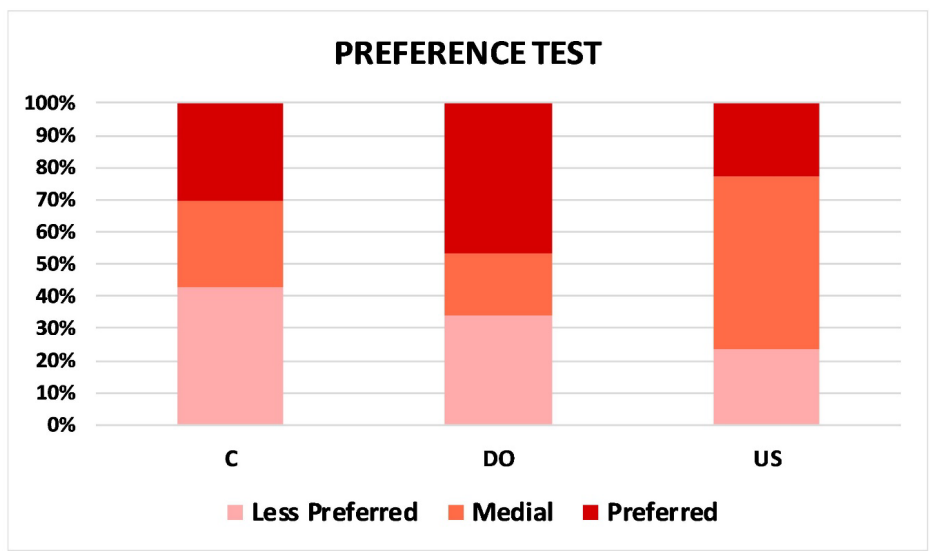

Figure 2. Sensory analysis of preference (\%) of the dehydrated beet type chips. Untreated (C); osmotic dehydration pre-treatment (DO), and ultrasonic pre-treatment (US).

The preference for the OD sample may have been a consequence of the method, which causes sensory alteration and/or modification of some compounds (Pingret et al., 2013). The presence of hypertonic sodium chloride solution promotes leaching of water-soluble compounds, such as mineral salts, aromas and dyes, which may have exerted an important role in the sensory preference for the beet chips treated with osmotic dehydration (Ahmed et al., 2016). The consequent use advantages of OD are that the immersion of product in osmotic agents avoids the $\mathrm{O}_{2}$ exposure of the product, the higher moisture content is allowed at the end of drying as salt uptake influences water sorption behavior of the product, it protects against the structural collapse during subsequent drying and it helps retain the shape of the dehydrated products (Bozkir et al., 2019; Chavan \& Amarowicz, 2012). 
The intermediate sensory rating for the US sample compared with the untreated sample (C) corroborated with Medeiros et al. (2016), who claim that this method can improve sensory characteristics. Bozkir et al. (2019) reported that were not statistically significant changes in the color values $\left(\Delta \mathrm{E}, \Delta \mathrm{C}\right.$, and Hue $\left.{ }^{\circ}\right)$, while Allahdad et al. (2019) and Konopacka et al. (2017) evidenced a more vivid and desirable color in the US treatment application previous to drying.

The PCA was performed to evaluate the data from the consumers' acceptance tests (Figure 3a) regarding the different treatments (C, OD and US). PC1 and PC2 explained 51.97\% and 29.31\% of the respective experimental data variance, accounting together for $81.28 \%$ of the variance. The PC1 x PC2 plot split the samples into three different groups, and the US and OD samples received the highest acceptance scores. The US and OD treatments did not affect flavor or taste significantly, and the untreated (C) samples received the lowest acceptance scores.

The HCA (Figure 3b and 3c) grouped the samples into two clusters according to the consumers' preferences. Cluster 1 comprised the untreated samples, and cluster 2 contained the OD and US samples. The pre-treated samples were in the opposite direction to the control samples, which was in accordance with the PCA. Nevertheless, it should be noted that the sensory tests were conducted with a specific public, i.e. soccer players aged 18-22. Therefore, further studies should be performed using a wider panel to evaluate the sensory properties of the beetroot chips. The sensory analysis indicated that both pre-treatments (OD and US) are viable ways to enhance the sensory properties of beetroot chips, which is important prior to marketing such a product.

A)

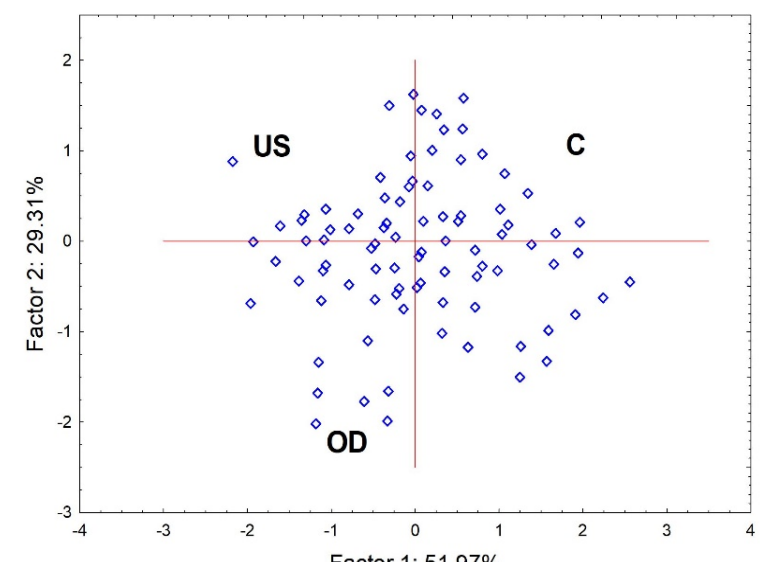

B)
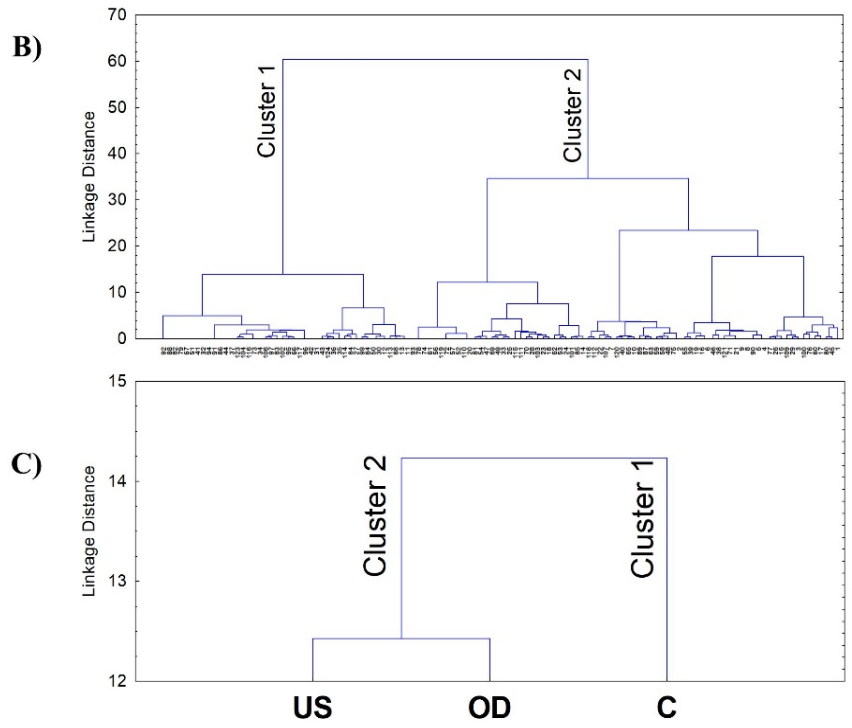

Figure 3. Sensory analysis of dehydrated beet type chips. Sample codes: US (ultrasound), OD (osmotic dehydration) and C (untreated - control). (A) PC1 X PC2 generated from a correlation-matrix PCA; (B) Cluster dendrogram constructed with Euclidean distances and Ward's linkage method; (C) Grouping of pre-treated (US and OD) and untreated (C) samples. 


\section{Conclusion}

The ultrasound (US) treatment promoted a higher drying rate when compared to samples pre-treated by osmotic dehydration (OD) with sodium chloride, and the untreated samples (C). The two-term exponential model showed that the $\mathrm{R}^{2}$ value presented a good correlation, indicating that the symmetry of the studied model was maintained and can be applied in the dehydration of beet chips. The US pre-treatment decreased the lipid, ash and energy values of the beet chips. The OD process resulted in higher sodium values. Beets without pre-treatment were the least preferred by the judges. Considering the fact that it provided the shortest drying time and obtained an intermediate level of preference, the US technique can be economically feasible to add value to beetroot and generate income for family farmers.

\section{Acknowledgements}

The authors gratefully acknowledge the technical resources provided through CAPES and CNPq (Case No. 552448/2011-7).

\section{References}

Aadil, R. M., Zeng, X. A., Han, Z., \& Sun, D. W. (2013). Effects of ultrasound treatments on quality of grapefruit juice. Food Chemistry, 141(3), 3201-3206. PMid:23871078. http://dx.doi.org/10.1016/j.foodchem.2013.06.008

Abe, T., \& Afzal, T. M. (1997). Thin-layer infrared radiation drying of rough rice. Journal of Agricultural and Engineering Research, 67(4), 289-297. https://doi.org/10.1006/jaer.1997.0170.

Ahmed, I., Qazi, I. M., \& Jamal, S. (2016). Developments in osmotic dehydration technique for the preservation of fruits and vegetables. Innovative Food Science \& Emerging Technologies, 34, 29-43. http://dx.doi.org/10.1016/j.ifset.2016.01.003

Allahdad, Z., Nasiri, M., Varidi, M., \& Varidi, M. J. (2019). Effect of sonication on osmotic dehydration and subsequent air-drying of pomegranate arils. Journal of Food Engineering, 244, 202-211. http://dx.doi.org/10.1016/j.jfoodeng.2018.09.017

Amami, E., Khezami, W., Mezrigui, S., Badwaik, L. S., Bejar, A. K., Perez, C. T., \& Kechaou, N. (2017). Effect of ultrasoundassisted osmotic dehydration pretreatment on the convective drying of strawberry. Ultrasonics Sonochemistry, 36, 286-300. PMid:28069213. http://dx.doi.org/10.1016/j.ultsonch.2016.12.007

Association of Official Analytical Chemists - AOAC. (2008). Official methods of analysis of the Association of Official Analytical Chemists. Gaithersburg: AOAC International.

Ávila, S., Hornung, P. S., Teixeira, G. L., Malunga, L. N., Apea-Bah, F. B., Beux, M. R., Beta, T., \& Ribani, R. H. (2019). Bioactive compounds and biological properties of Brazilian stingless bee honey have a strong relationship with the pollen floral origin. Food Research International, 123, 1-10. PMid:31284956. http://dx.doi.org/10.1016/j.foodres.2019.01.068

Azoubel, P. M., Baima, M. A. M., Amorim, M. R., \& Oliveira, S. S. B. (2010). Effect of ultrasound on banana cv Pacovan drying kinetics. Journal of Food Engineering, 97(2), 194-198. http://dx.doi.org/10.1016/j.jfoodeng.2009.10.009

Azoubel, P. M., da Rocha Amorim, M., Oliveira, S. S. B., Maciel, M. I. S., \& Rodrigues, J. D. (2015). Improvement of water transport and carotenoid retention during drying of papaya by applying ultrasonic osmotic pretreatment. Food Engineering Reviews, 7(2), 185-192. http://dx.doi.org/10.1007/s12393-015-9120-4

Barman, N., \& Badwaik, L. S. (2017). Effect of ultrasound and centrifugal force on carambola (Averrhoa carambola L.) slices during osmotic dehydration. Ultrasonics Sonochemistry, 34, 37-44. PMid:27773258. http://dx.doi.org/10.1016/j.ultsonch.2016.05.014

Bligh, E.G., \& Dyer, W. (1959). A rapid method of total lipid extraction and purification. Canadian Journal of Biochemistry and Physiology, 37(8), 911-917. PMid:13671378.

Borin, I., Frascareli, E. C., Mauro, M. A., \& Kimura, M. (2008). Efeito do pré-tratamento osmótico com sacarose e cloreto de sódio sobre a secagem convectiva de abóbora. Food Science and Technology (Campinas), 28(1), 39-50. http://dx.doi.org/10.1590/S0101-20612008000100008

Bozkir, H., \& Ergün, A. R. (2020). Effect of sonication and osmotic dehydration applications on the hot air drying kinetics and quality of persimmon. Lwt, 131, 109704. http://dx.doi.org/10.1016/j.lwt.2020.109704

Bozkir, H., Rayman Ergün, A., Serdar, E., Metin, G., \& Baysal, T. (2019). Influence of ultrasound and osmotic dehydration pretreatments on drying and quality properties of persimmon fruit. Ultrasonics Sonochemistry, 54, 135-141. https://doi.org/10.1016/j.ultsonch.2019.02.006

Brochier, B., Inácio, J. M., \& Noreña, C. P. Z. (2019). Study of osmotic dehydration of kiwi fruit using sucrose solution. Brazilian Journal of Food Technology, 22, 1-9. http://dx.doi.org/10.1590/1981-6723.14618

Chavan, U. D., \& Amarowicz, R. (2012). Osmotic dehydration process for preservation of fruits and vegetables. Journal of Food Research, 1(2), http://dx.doi.org/10.5539/jfr.v1n2p202 
Chhikara, N., Kushwaha, K., Sharma, P., Gat, Y., \& Panghal, A. (2019). Bioactive compounds of beetroot and utilization in food processing industry: a critical review. Food Chemistry, 272, 192-200. https://doi.org/10.1016/j.foodchem.2018.08.022

da Rosa, A. C. S., Stevanato, N., Iwassa, I., dos Santos Garcia, V. A., \& da Silva, C. (2019). Obtaining oil from macauba kernels by ultrasound-assisted extraction using ethyl acetate as the solvent. Brazilian Journal of Food Technology, 22, 1-10. http://dx.doi.org/10.1590/1981-6723.19518

Elias, N. D. F., Berbert, P. A., De Molina, M. A. B., Viana, A. P., Dionello, R. G., \& Queiroz, V. A. V. (2008). Avaliação nutricional e sensorial de caqui cv Fuyu submetido à desidratação osmótica e secagem por convecção. Food Science and Technology (Campinas), 28(2), 322-328. http://dx.doi.org/10.1590/S0101-20612008000200009

Fakhouri, F. M., Martelli, S. M., Caon, T., Velasco, J. I., \& Mei, L. H. I. (2015). Edible films and coatings based on starch/gelatin: Film properties and effect of coatings on quality of refrigerated Red Crimson grapes. Postharvest Biology and Technology, 109 57-64. https://doi.org/10.1016/j.postharvbio.2015.05.015.

Food and Agriculture Organization - FAO, \& World Health Organization - WHO. (2003). Nitrate (and potential endogenous formation of N-nitroso compounds) (Food Additive Series; 50). USA: FAO. Retrieved in 2020, April 15, from http://www.inchem.org/documents/jecfa/jecmono/v50je06.htm

Goula, A. M., Kokolaki, M., \& Daftsiou, E. (2017). Use of ultrasound for osmotic dehydration. The case of potatoes. Food and Bioproducts Processing, 105, 157-170. http://dx.doi.org/10.1016/j.fbp.2017.07.008

Henderson, S. M., \& Pabis, S. (1961). Grain drying theory II: Temperature effects on drying coefficients. Journal of Agricultural Engineering Research, 6, 169-174.

Instituto Adolfo Lutz - IAL. (2008). Métodos físicos-quimicos para análise de alimentos. In O. Zenebon, N. S. Pascuet, \& P. Tiglea (Eds.), Métodos físico-químicos para análise de alimentos. São Paulo: IAL.

Kiani, H., Karimi, F., Labbafi, M., \& Fathi, M. (2018). A novel inverse numerical modeling method for the estimation of water and salt mass transfer coefficients during ultrasonic assisted-osmotic dehydration of cucumber cubes. Ultrasonics Sonochemistry, 44, 171-176. https://doi.org/10.1016/j.ultsonch.2018.02.003

Konopacka, D., Cybulska, J., Zdunek, A., Dyki, B., Machlańska, A., \& Celejewska, K. (2017). The combined effect of ultrasound and enzymatic treatment on the nanostructure, carotenoid retention and sensory properties of ready-to-eat carrot chips. Lebensmittel-Wissenschaft + Technologie, 85, 427-433. http://dx.doi.org/10.1016/j.Iwt.2016.11.085

Li, M., Ye, B., Guan, Z., Ge, Y., Li, J., \& Ling, C. M. (2017). Impact of ultrasound-assisted osmotic dehydration as a pretreatment on the quality of heat pump dried tilapia fillets. Energy Procedia, 123, 243-255. http://dx.doi.org/10.1016/j.egypro.2017.07.257

Lomauro, C. J., Bakshi, A. S., \& Labuza, T. P. (1985). Moisture transfer properties of dry and semimoist foods. Journal of Food Science, 50(2), 397-400. http://dx.doi.org/10.1111/j.1365-2621.1985.tb13411.x

Medeiros, R. A. de B., Barros, Z. M. P., de Carvalho, C. B. O., Neta, E. G. F., Maciel, M. I. S., \& Azoubel, P. M. (2016) Influence of dual-stage sugar substitution pretreatment on drying kinetics and quality parameters of mango. Lebensmitte/Wissenschaft + Technologie, 67, 167-173. http://dx.doi.org/10.1016/j.lwt.2015.11.049

Mierzwa, D., \& Kowalski, S. J. (2016). Ultrasound-assisted osmotic dehydration and convective drying of apples: Process kinetics and quality issues. Chemical and Process Engineering - Inzynieria Chemiczna i Procesowa, 37(3), 383-391. https://doi.org/10.1515/cpe-2016-0031

Mirzayi, B., Heydari, A., \& Jabbari, A. (2018). The effects of Sucrose / NaCl / Time interactions on the osmotic dehydration of banana slices Efeitos de interações de Sacarose / NaCl / Tempo na desidratação osmótica de fatias de banana. Brazilian Journal of Food Technology, 21, e2017228.

Nowacka, M., Tylewicz, U., Laghi, L., Dalla Rosa, M., \& Witrowa-Rajchert, D. (2014). Effect of ultrasound treatment on the water state in kiwifruit during osmotic dehydration. Food Chemistry, 144, 18-25. PMid:24099537.

http://dx.doi.org/10.1016/j.foodchem.2013.05.129

Nowacka, M., Tylewicz, U., Romani, S., Dalla Rosa, M., \& Witrowa-Rajchert, D. (2017). Influence of ultrasound-assisted osmotic dehydration on the main quality parameters of kiwifruit. Innovative Food Science and Emerging Technologies, 41, 71-78. https://doi.org/10.1016/j.ifset.2017.02.002

Nowacka, M., Tylewicz, U., Tappi, S., Siroli, L., Lanciotti, R., Romani, S., \& Witrowa-Rajchert, D. (2018). Ultrasound assisted osmotic dehydration of organic cranberries (Vaccinium oxycoccus): Study on quality parameters evolution during storage. Food Control, 93, 40-47. https://doi.org/10.1016/j.foodcont.2018.05.005

Ozdemir, M., \& Devres, Y. O. (1999). The thin layer drying characteristics of hazelnuts during roasting. Journal of Food Engineering, 42.

Page, G. E. (1949). Factors influencing the maximum rates of air drying shelled corn in thin layers. Indiana: Purdue University.

Pingret, D., Fabiano-Tixier, A. S., \& Chemat, F. (2013). Degradation during application of ultrasound in food processing: a review. Food Control, 31(2), 593-606. http://dx.doi.org/10.1016/j.foodcont.2012.11.039

Prithani, R., \& Dash, K. K. (2020). Mass transfer modelling in ultrasound assisted osmotic dehydration of kiwi fruit. Innovative Food Science \& Emerging Technologies, 64, 102407. http://dx.doi.org/10.1016/j.ifset.2020.102407

Queiroz, V. A. V., Berbert, P. A., De Molina, M. A. B., Gravina, G. D. A., Queiroz, L. R., \& Deliza, R. (2007). Osmotic dehydration and convective drying of guava. Pesquisa Agropecuária Brasileira, 42(10), 1479-1486. http://dx.doi.org/10.1590/s0100-204x2007001000016 
Rahaman, A., Zeng, X. A., Kumari, A., Rafiq, M., Siddeeg, A., Manzoor, M. F., Baloch, Z., \& Ahmed, Z. (2019). Influence of ultrasound-assisted osmotic dehydration on texture, bioactive compounds and metabolites analysis of plum. Ultrasonics Sonochemistry, 58, 104643. PMid:31450325. http://dx.doi.org/10.1016/j.ultsonch.2019.104643

Ribeiro, A. S. C., Aguiar-Oliveira, E., \& Maldonado, R. R. (2016). Optimization of osmotic dehydration of pear followed by conventional drying and their sensory quality. Lebensmittel-Wissenschaft + Technologie, 72, 407-415. http://dx.doi.org/10.1016/j.Iwt.2016.04.062

Ricce, C., Rojas, M. L., Miano, A. C., Siche, R., \& Augusto, P. E. D. (2016). Ultrasound pre-treatment enhances the carrot drying and rehydration. Food Research International, 89(Pt 1), 701-708. PMid:28460968.

http://dx.doi.org/10.1016/j.foodres.2016.09.030

Sakooei-Vayghan, R., Peighambardoust, S. H., Hesari, J., \& Peressini, D. (2020). Effects of osmotic dehydration (with and without sonication) and pectin-based coating pretreatments on functional properties and color of hot-air dried apricot cubes. Food Chemistry, 311, 125978. https://doi.org/10.1016/j.foodchem.2019.125978

Sanjinez-Argandoña, E. J., Yahagi, L. Y., Costa, T. B., \& Giunco, A. J. (2018). Mango dehydration: influence of osmotic pretreatmentAnd addition of calcium chloride. Revista Brasileira de Fruticultura, 40(4), e-419. http://dx.doi.org/10.1590/010029452018419

Souza da Silva, E., Rupert Brandão, S. C., Lopes da Silva, A., Fernandes da Silva, J. H., Duarte Coêlho, A. C., \& Azoubel, P. M. (2019). Ultrasound-assisted vacuum drying of nectarine. Journal of Food Engineering, 246, 119-124. https://doi.org/10.1016/j.jfoodeng.2018.11.013

Tadesse, F. T., Abera, S., \& Solomon, W. K. (2016). Rehydration Capacity and Kinetics of Solar-Dried Carrot (Daucus carota) Slices as Affected by Blanching and Osmotic Pretreatments. International Journal of Food Engineering, 12(2), 203-210. http://dx.doi.org/10.1515/ijfe-2015-0210

Villamiel, M., Gamboa, J., Soria, A. C., Riera, E., García-Pérez, J. V., \& Montilla, A. (2015). Impact of power ultrasound on the quality of fruits and vegetables during dehydration. Physics Procedia, 70, 828-832. http://dx.doi.org/10.1016/j.phpro.2015.08.169

World Health Organization - WHO. (2016). Salt reduction. Geneva: WHO. Retrieved in 2020, April 15, from https://www.who.int/news-room/fact-sheets/detail/salt-reduction

Xin, Y., Zhang, M., \& Adhikari, B. (2013). Effect of trehalose and ultrasound-assisted osmotic dehydration on the state of water and glass transition temperature of broccoli (Brassica oleracea L. var. botrytis L.). Journal of Food Engineering, 119(3), 640647. http://dx.doi.org/10.1016/j.jfoodeng.2013.06.035

Yaldiz, O., Ertekin, C., \& Uzun, H. I. (2001). Mathematical modeling of thin layer solar drying of sultana grapes. Energy, London, 26(5), 457-465.

Zhao, J. H., Xiao, H. W., Ding, Y., Nie, Y., Zhang, Y., Zhu, Z., \& Tang, X. M. (2017). Effect of osmotic dehydration pretreatment and glassy state storage on the quality attributes of frozen mangoes under long-term storage. Journal of Food Science and Technology, 54(6), 1527-1537. PMid:28559612. http://dx.doi.org/10.1007/s13197-017-2584-x 